\title{
British Peace Activism and 'New' Diplomacy: \\ Revisiting the 1899 Hague Peace Conference
}

\section{Daniel Hucker}

\begin{abstract}
This analysis provides a re-appraisal of the 1899 Hague Conference by looking more closely at how citizen activists - notably in Britain but also transnationally - used it as a forum through which to press their agenda onto politicians and diplomatists. In so doing, this assembly existed as a stepping-stone between the 'old' diplomacy of the nineteenth century and the 'new' diplomacy of the twentieth. Peace activists identified and harnessed a growing body of progressive public opinion - on both a domestic and international scale - in the hope of compelling governments to take the necessary steps towards realising their ambitions of peace, disarmament, and international arbitration. Although the tangible outcomes of the 1899 Conference were limited, the precedents it established paved the way not only for further advances in international law, but also facilitated ever closer public and press scrutiny of international affairs into the twentieth century.
\end{abstract}

Within the many pages written about the diplomatic prelude to the First World War, the two Hague Peace Conferences of 1899 and 1907 are, if mentioned at all, routinely dismissed as 
peripheral events of little consequence. ${ }^{1}$ Although historians specialising in the history of international law and arms control have provided appraisals that are more favourable, ${ }^{2}$ such interpretations have largely failed to permeate the dominant narratives of the pre-1914 international scene provided by diplomatic and international historians. Steiner and Neilson, for example, note how the 'arbitrationists and reductionists were again defeated' at the 1907 conference, with no amount of press agitation or lofty political rhetoric able to reverse the 'political realities'. Despite recognising the two Hague conferences as the greatest success for a fledgling European peace movement, James Joll furnishes a similar verdict: it was a 'hollow' victory as few representatives arrived at The Hague 'in either an optimistic or a constructive mood'. These shortcomings invariably overshadow any positive accomplishments identified. Describing the outcomes of the 1899 Conference, John Young notes that progress was made in terms of voluntary arbitration and further codifying the rules of warfare, but little was achieved that could ultimately restrict the behaviour of states. ${ }^{3}$

More recently, there has been greater recognition of the Hague Conferences' achievements. Emily Rosenberg asserts that the gatherings 'electrified' the growing legions of peace activists, and that whilst their accomplishments have been frequently 'trivialized', these assemblies deserve praise for tapping into an escalating belief that legalistic mechanisms could govern the international sphere as effectively as they did the domestic. This growing belief was not restricted to marginal groups of jurists and academics but also encompassed the burgeoning peace movements that had become, as Margaret Macmillan remarks, so prominent by the late-nineteenth century. ${ }^{4}$ As a result, the two Hague Conferences can take their rightful place within what Stephen Wertheim describes as the 'prevailing historiographical paradigm' through which the emergence of an international 
society is seen as 'a progressive advance from power politics toward global community'. But although an increasingly enlightened and expanded 'public sphere' contributed to this progressive advance, the majority of public opinion - at least in Europe - remained, as William Mulligan reminds us, 'inclined towards defensive patriotism'. Peace was preferred, but there remained a willingness to accept war in certain circumstances; this philosophical stance, following Martin Ceadel's typology, is closer to pacificism than pacifism. ${ }^{6}$ In 1914 , politicians would exploit the prevalence of the former - what Sandi Cooper has labelled 'patriotic pacifism' - to ensure popular support for war. ${ }^{7}$

To be sure, the outbreak of war in 1914 makes it difficult to see the Hague Conferences as anything other than failures. They did not achieve their twin aims of reducing the level of armaments and substituting international arbitration for war. But it is crucial to distinguish between tangible results and more abstract legacies. As Jost Dülffer asserts, although undermined by governmental commitment to realpolitik, the Conferences nonetheless acted as 'a catalyst and a forum for international public opinion that grew stronger with the years and allowed hope for the future'. ${ }^{8}$ Mary Kaldor sees the Hague Conferences as 'significant' examples of an emergent global civil society, a precursor to the international non-governmental associations that would flourish in later years, notably those linked to the League of Nations and the International Labour Organisation. Indeed, Akira Iriye points to the proliferation of international non-governmental organisations after the Great War; in 1929, the League of Nations put the number of such organisations at $478 .{ }^{9}$ Hence Casper Sylvest urges one to look beyond the disappointing outcomes and instead view the Conferences as part of a 'long, incremental process' that might eventually deliver results much closer to the aspirations entertained by peace activists at the time. ${ }^{10}$ Such aspirations 
will be used here as a starting-point from which to re-assess the legacy of the first conference in 1899. This gathering marked a minor - but nonetheless significant - step on the path from the 'closed' diplomatic norms of the nineteenth century towards the more 'open' norms of the twentieth. As Hamilton and Langhorne note, 'new' diplomacy has two central tenets: first, it is more open to public scrutiny and control; second, it finds basis on the establishment of international forums to facilitate the peaceful resolution of international disputes. ${ }^{11}$ If the processes of international arbitration inaugurated at The Hague in 1899 tick the second box, then the impact of citizen activists, harnessing a latent public opinion behind their cause, arguably ticks the first.

The diplomatic climate of the late-nineteenth century appeared ill suited for a peace conference. It was a time of heightened nationalist tensions, imperial flashpoints, distinct power blocs, and the relentless growth of armaments. In spite of this international milieu, or perhaps because of it, the young Russian tsar, Nicholas II, issued a Rescript calling for a meeting of the Great Powers that would allow 'the great conception of universal peace to triumph over the elements of trouble and discord'. ${ }^{12}$ This diplomatic gesture caught many seasoned diplomats off-guard but warmed the hearts of a burgeoning global movement inspired by ideals of peace, disarmament, and international arbitration. Described as a 'thunderclap', the tsar's initiative revived a movement disenchanted by the failure of AngloAmerican and Franco-American arbitration initiatives during the 1890 s. ${ }^{13}$ Parts of Britain certainly warmly welcomed the Rescript. The Mayor of Leicester considered it "pregnant with the brightest hopes for civilization and humanity', and the East Northamptonshire Liberal Association 'unanimously and heartily approved' and hoped that all governments would meet the tsar's manifesto in 'the most cordial spirit'. The Women's Liberal 
Associations of Northumberland and Durham urged the British government to 'heartily cooperate in bringing about the International conference to discuss the reduction of armaments and the adoption of arbitration'. ${ }^{14}$ Indeed, women's organisations were often at the forefront of transnational citizen activism, and they invariably urged a serious discussion of the disarmament proposals. Over one million people signed a petition in favour of the tsar's initiatives that was sent to the delegates at The Hague by the Ligue des Femmes pour le Désarmement International. ${ }^{15}$

One of the most striking features of the Rescript was its focus on arresting the growth of armaments, a topic that had preoccupied the author of the book that inspired the tsar's invitation. It was Ivan Bloch's six-volume Is War Now Impossible? - published in English in abridged single-volume form during summer 1898, including a substantial preface detailing a conversation between Bloch and the British peace activist and journalist, W.T. Stead. Bloch railed against those who dismiss peace activists as 'Utopians', claiming instead that 'the real Utopians . . are those who believe in war [for they] are wasting the resources of civilisation'. The next war, continued Bloch, would be a long one, resulting in the 'bankruptcy of nations and the break-up of the whole social organisation' ${ }^{16}$ His argument that future wars would become so 'total' that no one side could ever emerge victorious, and that the costs of war - both human and financial - would become too high to contemplate, resonated with the tsar and aroused the hopes of peace activists across the world. One suggestion is that of all the hopes engendered by the 1899 conference, the disarmament question assumed the most importance in the eyes of global opinion. ${ }^{17}$

Diplomatic circles, however, met the Tsar's proposals with a fusion of realism and cynicism, few believing that arms limitation was possible. As the British conservative 
Unionist prime minister and foreign secretary, Lord Salisbury, remarked, 'it will be a very arduous task [to arrive at a formula which] would command the assent of all the European Powers' ${ }^{18}$ Elsewhere in Europe, the tsar's motives confronted cynicism. In Berlin, Kaiser Wilhelm II dismissed the proposal as an attempt to reduce the 'heavy drain on the resources' of the Russian Empire that precluded St Petersburg from keeping pace, militarily, with the other Great Powers. ${ }^{19}$ 'I'll go along with the conference comedy', he remarked in an oftquoted aside, 'but I'll keep my dagger at my side during the waltz'. ${ }^{20}$ The kaiser's cynical interpretation was widely shared in the foreign ministries and chancelleries of Europe, and this cynicism has done much to shape the dominant narrative of the 1899 Conference. To cynics, the tsar's initiative was motivated less by a deep-seated humanitarian impulse and more by a perceived need to redress the financial strains imposed on Russia by the arms race. Although peace enthusiasts lapped up the Rescript, wizened and hard-nosed European diplomats probed the tsar's agenda, dismissed its utopian aspirations, and continued to arm regardless.

Nowhere is this diplomatic cynicism more evident than in the letters of Eyre Crowe, the emerging German expert in the British Foreign Office. Although better known for his pejorative commentary of the 1907 gathering - which he attended - Crowe was no less contemptuous when dismissing the prospects of the first. On hearing of the Rescript, he expressed astonishment that 'anybody should feel any excitement' about it and despaired at how 'the silly rubbish goes down the throat of H.M. Govt. like butter'. The following year, with the Conference underway, Crowe noted sardonically how it 'goes on pacifying its own members' whilst being ignored by everyone else. ${ }^{21}$ But simply to dismiss the 1899 Conference as a talking-shop, full of platitudes and well-meaning rhetoric but short on 
substance, not only neglects the progress that was made, it disregards the growing influence of public opinion on diplomacy. Although Crowe could reject the Conference as a sideshow, of interest only to a handful of delegates and peace enthusiasts, the hopes it engendered captured the imagination of many. Furthermore, as was tacitly acknowledged in his earlier comments, these hopes began to permeate political and diplomatic circles. This was attributable, at least in part, to the tireless campaigning initiated by peace activists on a national and international scale.

In Britain, much credit for raising the public profile of the Conference belongs to Stead. As Ceadel notes, his 'indomitable drive' lent the peace movement an impetus lacking since the death of Joseph Sturge in 1859 , and Stead was eager to capitalise on the 'major opportunity' that had arisen courtesy of the tsar's intervention. ${ }^{22}$ From the moment of the Rescript's issue, Stead sought to establish a 'pilgrimage of peace', first in Britain and subsequently further afield. In late-1898, he was discernibly upbeat about the progress that had been made, telling the Austrian pacifist, Bertha von Suttner, that the movement 'is becoming more and more serious everywhere' with the potential to enrol one million volunteers 'if the spirit and the enthusiasm with which we have started' could be sustained. The groundswell of opinion mobilising behind the crusade convinced Stead that the means now existed to 'evoke the deep, heart felt aspirations of the masses of the nations, which have been silent too long'. ${ }^{23}$ Indeed, he was confident that a well-informed and well-educated public opinion might compel reluctant governments in the direction of peace. 'Everything . . $\therefore$, he wrote to the veteran Liberal politician, James Bryce, in October 1898, 'hangs upon the degree and extent to which our people in England rally to the banner which the young Tsar has unfurled'. 24 
Stead was also keen to lobby prominent diplomats and politicians, and in October 1898, he informed Lord Esher, another prominent Liberal, of his intention to tour the continent 'to see the sovereigns and statesmen of Europe [to] survey the present state of public opinion among those who are the leaders and directors of European thought'. ${ }^{25}$ Worried that 'hostile influences' would be marshalled to undermine benevolent tsarist intentions, Stead responded by publishing a weekly newspaper, War Against War!, that promoted the tsar's project. His campaign sought 'to give an intense stimulus to peace propaganda everywhere', and his pilgrimage culminated in a gathering in London of the National Convention of the British Crusade for Peace on 21 March $1899 .{ }^{26}$ At this assembly, the Liberal MP John Morley, cited in his absence, urged those present to 'organise serious opinion in favour of turning the Czar's proposals to effective account'. ${ }^{27}$ On 29 March, Arthur Balfour, in charge of the Foreign Office because of Salisbury's infirmity, received a delegation that according to the Daily News, 'represented the public opinion of the country', comprising of 'men and women of all classes and parties' anxious that the government seize the opportunity provided by the tsar's invitation. ${ }^{28}$

It was apparent that the British government must, at the very least, pay lip service to the idealist impulses exhibited by sections of the public. In this spirit, the British delegation to The Hague comprised some very able and distinguished diplomats, no more so than the chief delegate, Sir Julian Pauncefote. Having served as Britain's ambassador to the United States during the Venezuela boundary dispute, he played a pivotal role in resolving this crisis via international arbitration. ${ }^{29}$ Heartened by this success, Pauncefote and the American secretary of State, Richard Olney, set about concluding a more far-reaching Anglo-American Treaty of Arbitration. Signed in 1897, this treaty seemingly heralded a new age in which 
arbitration rather than war settled international differences. Although Pauncefote was disappointed when the American Senate rejected the Treaty, he carried his faith in arbitration into the Hague deliberations, where he was accompanied by Sir Henry Howard, the second representative, Admiral Sir John Fisher, the naval delegate, and Major-General Sir John Ardagh and Colonel Charles à Court, the military technical delegates. Before the British delegates were furnished with official instructions, Russia's foreign minister, Count Mouravieff, stipulated the two overriding aims of the assembly: first, to arrest the growth of armaments and, potentially, even reduce them; and second, to implement an international mechanism capable of preventing recourse to war, most likely through arbitration. ${ }^{30}$ Although Mouravieff gave primacy to disarmament, British officials felt that the best hopes for progress lay in arbitration.

The main explanation for the focus on arbitration was that Britain almost immediately rejected arms reduction as something to which it could not subscribe. The service departments were predictably keen to safeguard their existing levels of strength and, in a lengthy document within the official instructions given to the British delegates in 1899 , the War Office went to extravagant lengths to question the desirability of reducing the nation's armaments. Britain, it argued, must be absolutely sure that the Hague discussions were not an elaborate ruse designed to reduce its naval capabilities so that other European Powers might form 'a coalition' capable of challenging its maritime supremacy. In addition, Britain's recent rearmament was deemed a necessary measure 'of precaution and prudence' in light of the 'action of other states'. ${ }^{31}$ The War Office even demonstrated how increased armaments enhanced the prospects of peace and lessened the horrors of war. By comparing the Hundred Years War of the fourteenth century to the Seven Weeks War of the nineteenth, it argued that 
the clear diminution in the duration of conflicts was attributable to improvements in weaponry. It noted how the fourteenth century witnessed 77 years of war and just 23 years of peace; by the nineteenth century, there had been (thus far) 21 years of war and 78 years of peace. Finally, the War Office claimed that technological advances made wars more humane, reducing casualties whilst simultaneously facilitating a clearer distinction between combatants and non-combatants, a distinction not made in antiquity. ${ }^{32}$ The scope of the arguments forwarded in this document illustrates the seriousness with which the British government approached the Hague discussions.

Important, however, is that the government's rejection of disarmament was not entirely out of step with the ambitions of peace enthusiasts. In fact, the majority of peace activists had quickly jettisoned the loftier aims of disarmament in favour of more realisable outcomes elsewhere. Most 'peace' campaigns ahead of the 1899 Conference focused overwhelmingly on implementing arbitration as a substitute for war. The Interparliamentary Union had been vocal advocates of arbitration since its inception in 1889 and, in 1895, the Union's President, Belgian senator Édouard Descamps, noted with satisfaction that arbitration had already gained traction in popular opinion, within the press, and even within the parliaments and chancelleries of the world. ${ }^{33}$ The Hague Conference thus provided an unprecedented opportunity to realise some long-held ambitions, a fact not lost on the activists. As the head of the International Peace Bureau, Élie Ducommun, told von Suttner in May 1899, the impending conference was by far the 'most important question' for the Bureau at the present time. In a bid to maximise its potential, the Bureau bombarded official delegates with a 'fascicle' of essays, brochures, and assorted other documents emanating from a multitude of peace societies and prominent pacifists across Europe and North 
America. ${ }^{34}$ One was an essay penned by Ducommun himself outlining the evolution of the peace movement to 1899 , which noted the importance of 'winning over public opinion to ideas of concord and conciliation' as a means of compelling governments to resolve 'thorny issues' without recourse to war. This was achieved, stated Ducommun, courtesy of the 'dreamers'; their tireless work had ensured that public support for arbitration had grown year on year, to the extent that governments were now formally discussing the creation of a permanent court. ${ }^{35}$

Another document included in the fascicle was an overview of the multifarious demonstrations held across Europe and America in favour of the tsar's ambitious proposals. This report asserted that support was greater in Britain than elsewhere, the campaign engulfing the 'entire nation' thanks, in no small part, to Stead's tireless efforts. Even in Scotland, it was noted, where no national peace society currently existed, public support for the cause had been manifest in Glasgow, Dundee, Aberdeen, and Greenock. Furthermore, the campaign transcended social schisms, with women's organisations and working-class associations particularly prominent. ${ }^{36}$ But Stead's success in galvanising public support in Britain was not mirrored on the continent. Longstanding antagonisms undoubtedly contributed to this failure; from Paris, the veteran French pacifist, Frédéric Passy, noted in October 1898 that the issues dividing Britain and France - notably in light of military and diplomatic confrontation at Fashoda over control of the Nile River - 'unfortunately absorb the bulk of public attention'. Despite Passy's hope that British and French peace advocates could overcome such residual hostility and work together in a bid to win over public opinion, Stead soon encountered difficulties in mobilising his European counterparts. ${ }^{37}$ By lateFebruary 1899, he acknowledged that his plans for an international pilgrimage required 
scaling back. 'I naturally feel much disappointed', he confessed to von Suttner, stressing that they must now put a brave face on the affair in an effort to 'minimise the apparent failure'. 38 Nonetheless, the frequent liaison between peace activists on an international scale, coupled with the growing assertiveness of transnational organisations like the Interparliamentary Union and the International Peace Bureau, indicated that a fledgling spirit of genuine internationalism was challenging the dominance of nationalism.

The Conference formally opened on 18 May 1899. Although on the cusp of the twentieth century, the diplomatic norms of this era remained rooted very much in the nineteenth; 'old' diplomacy still prevailed over 'new', despite the efforts of activists like Ducommun, Stead, and von Suttner to make diplomats accountable to a wider corpus of popular opinion. For professional diplomatists, it was imperative that inter-state relations remain shrouded in the utmost confidentiality, most concurring with François de Callières' 1716 assertion that secrecy is the 'life of negotiations'. ${ }^{39}$ As a result, most delegates opposed any press intrusion into the conference's proceedings, viewing public opinion 'as a distraction from the work at hand'. ${ }^{40}$ But whilst the official proceedings took place behind closed doors, a broader civil society emerged around it, meeting socially and even running parallel fora as the official sessions took place behind closed doors. ${ }^{41}$ The secretary to the American delegation, Frederick Holls, welcomed the more 'open' forums for diplomatic dialogue:

[T]he importance of intimate and most attractive social intercourse between the delegates and the official society of The Hague should not be underestimated. Many a threatened misunderstanding was cleared away at some dinner table; many an 
important point was agreed upon informally, but nonetheless effectively, at a hurried interview on a corner sofa during a crowded evening reception. ${ }^{42}$

For others, however, it was an unwelcome distraction. Germany's first delegate, Count Münster, repeatedly denounced the 'pack of rabble' - notably pacifists, socialists, women, and Jews - who continued to assemble unofficially with a view to promoting the core objectives of the Conference. ${ }^{43}$

Stead also sought to circumvent the diplomats' proclivity for secrecy by tapping into his sources for frequent updates that he then published in his own newspaper, the Dagbladin English, French and Dutch - that subsequently informed press coverage throughout the world. C.P. Scott of the Manchester Guardian praised Stead's endeavour, stating that he 'must feel a parental satisfaction' over the good work achieved. Indeed, Scott considered the Conference to have been 'splendid right through', expressing surprise about so much accomplished. 'Personally', he wrote, 'I had no expectation of living to see anything so good in the line of international good-will' ${ }^{44}$ Scott's positive appraisal of the Conference was largely attributable to the fact that realistic goals vis-à-vis arbitration usurped the more ambitious aim of arresting armaments: the issue of disarmament was simply the subject of a 'platonic' resolution that invited governments to investigate the desirability of limiting arms spending. ${ }^{45}$ But the realisation that something beneficial might be achieved with regard to arbitration greatly encouraged even those participants harbouring low expectations. The chief American delegate, Andrew Dickson White, was initially sceptical as to the possibility of positive outcomes: 'probably, since the world began, never has so large a body come together in a spirit of more hopeless scepticism as to any good result'. However, just two days later, 
he was 'considerably encouraged', the prevailing pessimism 'passing away' as hopes for tangible results - particularly in the domain of arbitration - increased. ${ }^{46}$

Arbitration would ultimately provide the most enduring outcome of the Conference the establishment of the Permanent Court of International Arbitration. As Ardagh remarked, despite failing to deliver the "conclusions which the Utopian fanatics of the world believed to be inevitable', the conference had 'done much good' elsewhere. ${ }^{47}$ This view echoed with the Russian delegate, Feodor de Martens, who concluded that whilst the Utopians - 'the most dangerous enemies of international law' - will have been disappointed, the wisdom of 'practical statesmen' had prevailed by focusing only on the achievable. ${ }^{48}$ Some scholars, in particular historians of international law who emphasise the significance of the arbitration scheme and the subsequent creation of the Permanent Court, share this contemporary appraisal. Frits Kalshoven notes that the 1899 Conference not only laid the foundations for the present-day International Court of Justice. It also implanted the idea 'that arsenals cannot be permitted unlimited growth both in a quantitative and qualitative sense', an idea that despite being unable to arrest the growth of armaments in the short-term 'would bear always modest - fruit in the century that followed'. Kalshoven observes further that efforts to codify the rules of war marked 'an important step' towards the further progress witnessed in the latter-half of the twentieth-century. ${ }^{49}$ Christopher Greenwood concurs. He argues that although the 'high hopes' entertained in 1899 were 'so cruelly and extensively disappointed' by the destructive conflicts that followed in its wake, one must not overlook the 'achievements of the law-making process', which ensured that the 'laws of war at the end of the 20th century are far more advanced than they were at its outset' ${ }^{50}$ 
Unsurprisingly, peace enthusiasts were even more ebullient in their appraisals of the Conference. George H. Perris, editor of Concord, the journal of the International Arbitration and Peace Association [IAPA], noted that 'cool-headed diplomatists were inspired by the occasion of their meeting'. They ensured that the prevailing scepticism 'gave way gradually to a spirit of concord, an appreciation of the magnitude of the work of the Conference, and a determination, at all costs, to do something definite toward its accomplishment'. 51 Proponents of pacifism and international arbitration deemed the Conference worthy of celebration. Perris labelled it 'the most promising inter-governmental assembly ever held', establishing a precedent through which an imperfect Peace [can be moulded] into perfect and enduring Concord'. ${ }^{52}$ W. Evans Darby, secretary of the Peace Society, proclaimed 'the opening of a new era for mankind' in which the adoption of 'the Arbitration Scheme was in itself an epoch-making event'. Although acknowledging that war had not been eliminated, the Conference 'at least succeeded in interposing new obstacles in the way of its commencement and in extending, systematising, and organising the influences for making peace'. 53

Several official delegates shared these positive appraisals. Holls told von Suttner that his experiences at the conference had been more than a 'beautiful dream' as the entire occasion had assumed 'much more reality and practical value than a dream [amounting to] a great step forward'. ${ }^{54}$ Even The Times acknowledged that the initial 'diplomatic stiffness' and mutual distrust had given way to a genuine belief that 'more fruitful developments' were possible. ${ }^{55}$ Stead also dwelt on the positives, applauding the Conference for cultivating a 'good esprit de corps and a frank friendly fraternity of feeling'. He also welcomed Pauncefote's arbitration scheme, commenting how something previously dismissed as 
idealistic had become a practical reality. Stead's recognition of the shortcomings, however, tempered his enthusiasm. The kaiser had been consistently obstructive whilst the French proved reluctant to embrace arms limitation despite the goodwill and enthusiasm of their delegates - notably Léon Bourgeois and Baron d'Estournelles de Constant. More critically, the arbitration machinery lacked compulsion, relying solely on 'the power of public opinion, the resolution of the peoples that their Governments shall use arbitration before proceeding to war' ${ }^{56}$

Although Stead was confident that the growing influence of public opinion might yet reduce the likelihood of war, it was clear that much work remained. The key was sustained propaganda and education, meaning that peace activists on a global scale must continue to press their case tirelessly. The 1899 conference, continued Stead, would make this work easier:

In the crusade of last winter we were hindered by political and national prejudices against the Russia autocracy, and thousands of people in Europe, including the great Socialist Party in France and Germany, refused to lift a finger in aid of a movement which had otherwise their cordial sympathy. After to-day, we have no need to base our appeal on the Russian proposals alone. The aspiration after an arrest of armaments has received the formal benediction of the representatives of all the Powers; and it is in the name of the Conference that we will resume our work, and with a new confidence of victory. ${ }^{57}$

To mobilise public opinion behind further international agreement, a 'vigorous' propaganda was needed: the 'Governments have made the machine, but it is now for the peoples to see that the machine is made use of ${ }^{58}$ Perris concurred, noting that 'monarchs and statesmen' 
would only use the machinery created at The Hague if so persuaded by 'a popular public demand'. To generate a sufficient demand, it was imperative that the peace societies continue 'their task of agitation and education'. ${ }^{59}$ Stead, Perris, and like-minded individuals were convinced that 'popular sentiment' could bend intransigent statesmen around to their will. For Evans Darby, the 1899 gathering 'furnished a new illustration of the power of public opinion' during which the 'force and influence of public sentiment' was apparent to all in attendance. ${ }^{60}$ The Hague Conference was the latest example of an emergent 'body of international law' that relied solely on the 'moral sanction' of public opinion. The arrangements made, despite lacking compulsion, were 'more largely recognised as the judgment and conscience of mankind, to which no nation can persistently defy and maintain its standing in the family of nations', 61

The International Peace Bureau also celebrated the constructive outcomes achieved at The Hague. The 1900 Universal Peace Congress in Paris expressed satisfaction at the 'positive steps' that had been taken in the direction of international law but regretted its failure to make arbitration obligatory. Overall, however, the positives outweighed the failures, to the extent that the Congress even suggested that the old adage - 'Si vis pacem para bellum' - had been disproved, not only by the efforts of the peace activists but also by those statesmen and politicians, notably the tsar, who had come to recognise the 'ruinous results' of war. ${ }^{62}$ That such a conference convened at all was interpreted as evidence of public opinion's growing influence on diplomatic procedure. Passy told the conference that governments would eventually have to succumb to the 'pressure of public opinion', a view echoed by d'Estournelles de Constant at the 1901 Congress in Budapest: 'Today it is not the 
government that leads opinion; it is opinion that leads the government'. In the face of a hostile public, he asserted, no government could now wage an unjust war. ${ }^{63}$

It is apparent that one of the outcomes of the 1899 Conference was optimism that it would be a precursor of future assemblies and, above all, of a more peaceful century ahead. As Pauncefote articulated so eloquently in his final report to London, this unprecedented meeting of the 'great family of nations' would ensure that the 'new century will open with brighter prospects of peace'. ${ }^{64}$ For White, the 'mere assembling of such a body for such a purpose' was a substantial step forward, a gain surpassed only by the 'the positive outcome of its labors'; Stead asserted that 'the Conference itself is its own sufficient justification ... the beginning of the organisation of the world-unit'. ${ }^{65}$ To build upon this 'first step', d'Estournelles de Constant told Stead, the public must ensure that their governments 'don't stop half way'. ${ }^{66}$ It was thus incumbent upon the fledgling network of peace activists to keep the issue of peace firmly on the public agenda, as Stead had done throughout the 1899 Conference. As Pauncefote later commented, Stead had played an important part 'in keeping on the great cause by [his] indefatigable exertions in the Press \& otherwise ${ }^{67}$ However, events unfolding in South Africa would sorely test the chances of keeping ideas of peace and arbitration at the forefront of the public's consciousness.

The denouement of the Conference coincided with an escalating crisis in the Cape that now teetered on the brink of all-out war between Britain and the South African Boers. The subsequent military struggle that would dominate the political and diplomatic landscape for the next three years shattered the confidence and optimism generated at The Hague. The wave of public fervour and enthusiasm in Britain that greeted the outbreak of the Second Boer War certainly disoriented the British peace movement. There was not, at least initially, 
a hostile public capable of restraining the government. Perris told Ducommun on 23 October 1899 how he had been 'busy fighting this infernal reaction of murderous jingoism'. 'We are ashamed of our weakness', he continued, but assured Ducommun that all involved in the British peace movement were fighting as hard as they could, and that despite the 'terrible mass of jingo feeling', he remained confident that 'the majority of the nation would vote against this wicked war if it had the opportunity'. Above all, Perris lamented the all-powerful 'governing class \& its press' for stoking the fires of warlike patriotism. ${ }^{68}$

J.F. Green, the secretary of the IAPA, expressed similar sentiments. He informed Ducommun in mid-November that "this wicked war which we have forced on the unfortunate Boer' had triggered in Britain a 'dreadful outbreak of "jingoism", the likes of which had not been seen 'since 1878 , \& then, as far as I remember, it was not as widespread as now'. Though rather disillusioned, Green remained sanguine that the jingoist wave 'will pass away as it did before', and that British peace advocates must meanwhile stay true to 'the spirit of the great saying - Magna est veritas, et pravalebit'. ${ }^{69}$ Stead also found the situation prompted by the Transvaal war intensely frustrating, and he campaigned from its beginning against British policy there. The unwillingness of the rest of the British peace movement notably the Peace Society - to condemn British actions in the Cape frustrated him. ${ }^{70}$ Stead was particularly forthright at the 1901 Peace Congress in Glasgow, hoping that delegates would eschew 'namby-pamby resolutions' in favour of expressing outright condemnation designed to arouse 'an explosion of pacific sentiment'. 'I see precious little explosion here', he lamented, 'and if a peace congress will not explode, how do you think the general public will do so? ${ }^{, 71}$ 
Although Stead and a small cohort of like-minded activists were far from representative of mainstream public sentiment, their crusade aroused considerable sympathy amongst peace advocates on the Continent. In December 1899, Ducommun expressed his 'great admiration' for the courage that had been shown by Stead and his fellow 'friends of peace and international justice' during this time of great difficulty. ${ }^{72}$ For British men in particular, opposing the South African war saw them publicly chastised as effeminate and physically targeted by jingoistic mobs. In this context, as Eliza Riedi has noted, women were 'privileged' within the pro-Boer campaign, rarely targets of violence, and clearly immune to the stigma of emasculation attached to their male counterparts. ${ }^{73}$ Consequently, female activists were pivotal in forcing the British public to re-evaluate the righteousness of their crusade in the Cape, especially after Emily Hobhouse's revelations concerning British atrocities against Boer women and children. ${ }^{74}$ As unease with the war spread in Britain, Stead sensed an opportunity to re-invigorate the processes of international law established in 1899. He was convinced that 'the public opinion of the world' would agree that 'a stronger Power' had no right to eliminate a smaller one having refused the latter's appeal for arbitration. Despite acknowledging that support for such a campaign would struggle to gain traction in Britain, Stead told Ducommun that 'this is the psychological moment for the International Union to take its first public act, and to make itself the organ of the conscience of mankind, ${ }^{75}$

The International Peace Bureau had not been entirely inactive, making various representations to the British and neutral governments in the hope of securing 'good offices' for the mediation of the conflict. It had also issued circulars and appeals to constituent members around the globe. ${ }^{76}$ At the same time, the Bureau's annual congresses persistently 
forwarded proposals aimed at advancing the cause of arbitration and international law, apparently undeterred by the failure of prevailing mechanisms to resolve existing conflicts. Indeed, two years after war in the Transvaal ended, the Russo-Japanese War began, another conflict seemingly impervious to peaceful resolution. Simultaneously, the European Powers moved inexorably into ever more ominous blocs whilst continuing to rearm at a frightening pace. ${ }^{77}$ The portents for any embellishment of the 1899 advances were far from promising. As d'Estournelles de Constant warned President Theodore Roosevelt in 1902, the Hague court was dying of inertia. ${ }^{78}$ The whole project was in desperate need of renewed impetus and vigour, a fact recognised by peace enthusiasts across the world. In 1904, both the Lake Mohonk Conference on International Arbitration and a delegation representing the Interparliamentary Union lobbied Roosevelt, calling on the American president to initiate a new international conference at The Hague.

Roosevelt willingly picked up the baton and his secretary of State, John Hay, issued a circular on 21 October 1904 calling for a second gathering at The Hague with the purpose of completing the 'postponed work of the first conference' ${ }^{79}$ Its reception was mostly favourable; in London, the foreign secretary, the conservative Unionist Lord Lansdowne, informed the American ambassador that His Majesty's Government would derive great pleasure from co-operating with Washington 'in so important a matter' ${ }^{80}$ As the date of the next conference approached, there appeared to be even more reason for optimism, especially from the perspective of British peace activists. The Liberals' landslide election victory in early 1906 on a ticket of 'peace, retrenchment and reform' was a huge fillip for those harbouring hopes of major advances not only in arbitration but also in disarmament. After the disaster that befell the movement with the outbreak of the Boer War, this election appeared to 
mark a partial revival of the 'reputation of the public'. ${ }^{81}$ Once again, an enlightened and progressive public opinion came to the fore, compelling the new Liberal administration to take very seriously the hopes that were entertained ahead of the 1907 gathering.

It is beyond the scope of this analysis to assess the proceedings and outcomes of the 1907 Conference, but it is apparent that the accomplishments of 1899 were both a help and a hindrance. On the one hand, it established a precedent, laying foundations that future conferences could build upon with the support of a vibrant and vigorous peace movement. On the other, the hopes generated by the 1899 meeting led to even more far-reaching aspirations in 1907, particularly regarding disarmament. At the same time, despite the genuinely positive outcomes of 1899 - notably the establishment of the Arbitration Treaty it clearly failed to prevent conflict or arrest the growth of armaments. In fact, international tensions increased between 1899 and 1907, greatly diminishing the prospects for arbitration and disarmament. ${ }^{82}$ But the disappointment that would accompany the lack of progress in 1907 was not simply attributable to the deteriorating international situation. In part, it resulted from the heightened optimism that had resulted from the 1899 Conference.

There is no doubt that the hopes aroused by the tsar's Rescript had been sizeable, particularly within the emergent peace movement. As de Martens noted in the immediate aftermath, no prior conference had 'aroused so many hopes and so much opposition as the Conference at The Hague' ${ }^{83}$ It is also true that opposition was most prevalent in political and diplomatic spheres hence the almost immediate rejection of disarmament in favour of making gains in the domain of international arbitration. But two points need to be borne in mind here: first, most peace activists in Britain, despite some lofty rhetoric, shared the diplomats' view that disarmament was impracticable so instead focused on arbitration; second, the 
genuine progress that was made with regard to arbitration meant that much of the initial political and diplomatic cynicism soon dissipated. Nobody suggested that war had become obsolete - the Boer War and the Russo-Japanese War illustrated this all too clearly - but there were reasons to believe that the first step had occurred and that future assemblies could build upon the foundations laid. It also explains why the aims of peace activists ahead of the 1907 Conference outran what was practicable or likely.

Above all the 1899 Conference demonstrated the reach of peace activists, not only influencing governments but also reaching out to educate public opinion on issues of war and peace. This reach would grow further as the 'new' diplomacy that was emerging by 1899 meant that diplomats would struggle to exclude the press and public from their deliberations as they had tried to do - not entirely successfully - at the first Hague Conference. ${ }^{84}$ Indeed, there was a tangible sense amongst those in attendance in 1899 that times were already beginning to change, and that citizen activists could exert an influence; in May 1899, it was noted in Punch, albeit sardonically, that 'The Tsar of All the Russians plays second fiddle, whilst [Stead] leads the orchestra' ${ }^{85}$ Diplomats also began to acknowledge this transition. de Martens suggested that the consultations 'were not secret negotiations', but were instead a 'reciprocal exchange of ideas in open session'. Another delegate - writing anonymously but almost certainly an American - went further still, suggesting that the 'quietude of Cabinet negotiations is replaced by the clamour of public discussions' ${ }^{86}$ In this regard, it is worth recalling Hamilton and Langhorne's definition of 'new' diplomacy, specifically the requirement that it be open to public scrutiny and based on the peaceful resolution of quarrels. The 1899 Hague Conference certainly indicated that progress was being made, but the extent to which a more 'open' and 'accountable' diplomacy had been ushered in is more 
debatable. After all, as Hamilton and Langhorne remind us, the majority of the deliberations at the Paris Peace Conference of 1919-1920 transpired behind closed doors, the press only admitted to the plenary sessions. ${ }^{87}$

One of the reasons persuading even Woodrow Wilson of the need to keep negotiations secret was the perceived volatility of public opinion. Nevertheless, not only diplomats feared that a volatile - and potentially vindictive - public opinion might result in imprudent actions. Many members of the emergent civil society, and particularly advocates of international arbitration and arms limitation, shared these concerns and had consistently preached in the years preceding 1914 the need to 'educate' public opinion against jingoism and towards a spirit of internationalism and goodwill. At the 1907 National Arbitration and Peace Congress in New York, just before the Second Hague Conference began, Felix Adler reminded delegates of Plato's warnings concerning the capricious nature of public opinion, but nonetheless concluded that education and propaganda could be used to turn a volatile 'public opinion' into a more stable 'public reason'. ${ }^{88}$ This faith in a progressive public opinion was widespread within the transnational peace movement, a movement increasingly capable of influencing politicians and diplomats. If the success of a global civil society is contingent on 'their capacity to mobilize and on the responsiveness of authorities', ${ }^{89}$ the movement in favour of peace had had been relatively successful in 1899. Moving forward, pressure from the likes of the Lake Mohonk group and the Interparliamentary Union stimulated Roosevelt to press ahead with the 1907 Conference, whilst the perceived demands of British public opinion certainly encouraged the Liberal government to urge a serious discussion of arms limitation at that meeting. That these discussions came to nought, and that the wider efforts of international peace activists failed to provide the necessary antidote to the 
jingoism and nationalistic fervour of 1914 is certainly a tragedy, but not one, perhaps, that should be allowed to completely overshadow the genuine progress that had been made.

Notes

${ }^{1}$ See for example the foreword to the collection of official British documents edited by G.P. Gooch and H. Temperley, British Documents on the Origins of the War, 1898-1914, Volume III: Arbitration, Neutrality and Security (London, 1932).

${ }^{2}$ See for example the contributions by Frits Kalshoven and Christopher Greenwood in Frits Kalshoven ed., Centennial of the First International Peace Conference: Reports and Conclusions (The Hague, 2000). On the issue of arms control, see Scott Keefer, 'Great Britain and Naval Arms Control: International Law and Security, 1898-1914', (PhD dissertation, London School of Economics, 2011); Jost Dülffer, 'Chances and Limits of Armaments Control, 1898-1914', in Holger Afflerbach and David Stevenson, eds., An Improbable War: The Outbreak of World War I and European Political Culture before 1914 (Oxford, 2007).

${ }^{3}$ Zara Steiner and Keith Neilson, Britain and the Origins of the First World War, 140; James Joll, The Origins of the First World War, 258-59; John Young, Britain in the Twentieth Century (London, New York, 1997), 13.

${ }^{4}$ Emily S. Rosenberg, 'Transnational Currents in a Shrinking World', in idem., ed., A World Connecting, 1870-1945 (Cambridge, MA, 2012), 836; Margaret MacMillan, The War That Ended Peace: How Europe Abandoned Peace for the First World War (London, 2013), 27374. 
${ }^{5}$ Stephen Wertheim, 'The League of Nations: a retreat from international law?' Journal of Global History, 7(2012), 211. Prominent within the 'prevailing historiographical paradigm', as outlined by Wertheim, are G. John Ikenberry, After Victory: Institutions, Strategic Restraint, and the Rebuilding of Order after Major Wars (Princeton, NJ, 2001); Akira Iriye, Global Community: The Role of International Organizations in the Making of the Contemporary World (Berkeley, CA, 2002). Geoffrey Best, 'Peace conferences and the century of total war: the 1899 Hague Conference and what came after', International Affairs, 75/3(1999), 620 also sees the peace movements as part of a 'humming transnational civil society' that was emerging on the threshold of a new century.

${ }^{6}$ William Mulligan, The Origins of the First World War (Cambridge, 2010), 175; Martin Ceadel, Pacifism in Britain, 1914-1945: The Defining of a Faith (Oxford, 1980), 1-8.

${ }^{7}$ See Sandi Cooper, Patriotic Pacifism: Waging War on War in Europe, 1815-1914 (Oxford, 1991); idem., 'The Reinvention of the 'Just War' among European Pacifists before the First World War', in Harvey L. Dyck, ed., The Pacifist Impulse in Historical Perspective (Toronto, 1996), 303-19.

${ }^{8}$ Dülffer, 'Limits of Armaments Control', 111.

${ }^{9}$ Mary Kaldor, Global Civil Society: An Answer to War (Cambridge, 2003), 87; Akira Iriye, Global Community, 19-28.

${ }^{10}$ Casper Sylvest, British Liberal Internationalism, 1880-1930: Making Progress? (Manchester, 2009), 90. A similar appraisal of the legacy of the 1899 Conference is provided by David D. Caron, 'War and International Adjudication: Reflections on the 1899 Peace Conference', American Journal of International Law, 4(2000), 4. 
${ }^{11}$ Keith Hamilton and Richard Langhorne, The Practice of Diplomacy: Its Evolution, Theory and Administration, second edition (London, 2011), 142.

${ }^{12}$ Russian circular signed by Count Mouravieff [foreign minister], 12 August 1898, cited in Shabtai Rosenne, ed., The Hague Peace Conferences of 1899 and 1907 and International Arbitration: Reports and Documents (The Hague, 2001), 23-24.

${ }^{13}$ Cooper, Patriotic Pacifism, 97.

${ }^{14}$ All cited in 'The Czar's Peace Proposals', Daily News [London] (10 November 1898).

${ }^{15}$ Sandi Cooper, 'French Feminists and Pacifism, 1889-1914: The Evolution of New Visions', Peace \& Change, 26/1(2011), 13. See also idem., Patriotic Pacifism, 98.

${ }^{16}$ I.S. Bloch, Is War Now Impossible? Being an Abridgment of 'The War of the Future in its Technical, Economic and Political Relations' (London, 1899), ix-x, 349.

${ }^{17}$ Marc Cogen, Democracies and the Shock of War: The Law as a Battlefield (Farnham, 2012), 81 notes that 'popular enthusiasm' had been 'immense' on this issue.

${ }^{18}$ Salisbury to Scott [Moscow], 14 February 1899, FO [Foreign Office Archives, The National Archives, Kew] 412/65.

${ }^{19}$ Lascelles [Berlin] to Lord Salisbury, 22 December 1898, Ibid.

${ }^{20}$ Cited in MacMillan, War That Ended Peace, 279.

${ }^{21}$ Crowe to his mother, 1 September 1898 and 7 July 1899, Crowe [Eyre Crowe Papers, Special Collections, Bodleian Library, Oxford] MS. Eng. d. 2900.

${ }^{22}$ Martin Ceadel, Semi-Detached Idealists: The British Peace Movement and International Relations, 1854-1945 (Oxford, 2000), 152. 
${ }^{23}$ Stead to von Suttner, 28 December 1898, von Suttner [Bertha von Suttner Papers, International Peace Movement, League of Nations Archive, United Nations Office, Geneva] BvS/28/366-1/5.

${ }^{24}$ Stead to Bryce, 11 October 1898, Bryce [James Bryce MSS, Bodleian Library, Oxford] 140.

${ }^{25}$ Stead to Esher, 3 September 1898 ESHR [2 ${ }^{\text {nd }}$ Viscount Esher MSS, Churchill Archive Centre, Churchill College, Cambridge] 5/8.

${ }^{26}$ W.T. Stead, 'Topic of the Month', Review of Reviews (December 1898). For more on this see Keith Hamilton, 'Britain and The Hague Peace Conference of 1899', in Keith Hamilton and Edward Johnson, eds., Arms and Disarmament in Diplomacy (London, 2008), 11.

27 'The Crusade of Peace', Standard (22 March 1899).

28 'The Agitation for Peace', Daily News (30 March 1899).

${ }^{29}$ For more on this, see Duncan Andrew Campbell, Unlikely Allies: Britain, America and the Victorian Origins of the Special Relationship (London, 2007), 188-91.

${ }^{30}$ Scott to Salisbury, 12 January 1899, FO 412/65.

31 'Draft of instructions for Peace Conference, 1899', nd, Ardagh [Sir John Ardagh Papers, Manuscript Collections, The National Archive, Kew] PRO 30/40/15. On the top of this document was a handwritten note: 'This was finally sent as a memo by Sir J. A. in which Lord Lansdowne concurred'. The actions taken by other Powers could refer not only to Germany, but also to recent improvements to the French and Russian fleets; see Arthur J. Marder, The Anatomy of British Sea Power (New York, 1940), 343-45.

32 'Draft of instructions for Peace Conference, 1899', nd, Ardagh PRO 30/40/15. 
33 'Essai sur l'organisation de l'arbitrage international', Edouard Descamps, adopté par le Conférence Interparlementaire de Bruxelles, 1895, International Peace Bureau [hereafter IPB] [IPB, 1892-1914, League of Nations Archive, United Nations Office, Geneva] 237/5.

${ }^{34}$ The distribution of this 'fascicle', along with the details of its contents, was reported in the VIIIe Rapport du Bureau International de la Paix sur la gestion et ses comptes, 1 juillet au 30 juin 1899, IPB 237/7.

${ }^{35}$ Elie Ducommun, 'Précis historique du mouvement en faveur de la Paix', 1899, IPB 237/5.

36 'Rapport sur les manifestations de 1898 et 1899 pour appuyer l'initiative du Tzar', Ibid.

${ }^{37}$ Passy to Stead, 21 October 1898, STED [W.T. Stead Papers, Churchill College, Cambridge] 1/59.

${ }^{38}$ Stead to von Suttner, 24 February 1899, von Suttner BvS/28/366-1/7.

${ }^{39}$ François de Callières [H.M.A. Keens-Soper and Karl W. Schweizer, eds.], The Art of Diplomacy (Lanham, MD, 1994); de Callières' treatise was originally published in 1716, essentially constituting a diplomatic manual that soon became essential reading for European diplomatists.

${ }^{40}$ Caron, 'International Adjudication', 16.

${ }^{41}$ Kaldor, Global Civil Society, 87.

${ }^{42}$ Holls speech to the Lake Mohonk Conference, 6 June 1900, in Report of the Sixth Annual Meeting of the Lake Mohonk Conference on International Arbitration (1900), 9-10.

${ }^{43}$ Cooper, Patriotic Pacifism, 102.

${ }^{44}$ Scott to Stead, 10 August 1899, STED 1/64.

${ }^{45}$ Solomon Wank, 'Diplomacy against the Peace Movement: The Austro-Hungarian Foreign Office and the Second Hague Peace Conference of 1907', in idem., ed., Doves and 
Diplomats: Foreign Offices and Peace Movements in Europe and America in the Twentieth Century (Westport, CT, 1978), 64.

${ }^{46}$ Andrew Dickson White, Autobiography of Andrew Dickson White, Volume II (London, 1905), 250-51, 259.

${ }^{47}$ Ardagh to Senator Sir James Gowan [Barrie, Ontario], 29 July 1899, Ardagh PRO $30 / 40 / 15$.

${ }^{48}$ F. de Martens, 'International Arbitration and the Peace Conference at The Hague', North American Review, 169/516(1899), 604.

${ }^{49}$ Frits Kalshoven, 'Introduction' in idem., Centennial, 4-5.

${ }^{50}$ Christopher Greenwood, 'International Humanitarian Law (Laws of War)', in Ibid., 257.

${ }^{51}$ G.H. Perris, 'The Peace Conference at The Hague: The Good "Dream" Comes True at Last', in idem., ed., A History of the Peace Conference at The Hague (London, 1899), 8.

${ }^{52}$ Ibid., 9-10.

${ }^{53}$ W. Evans Darby, The Peace Conference at The Hague: Its History, Work and Results (London, nd [presumably 1899]), 49-50.

${ }^{54}$ Holls to von Suttner, 23 September 1899, von Suttner BvS/20/247-2/2.

${ }^{55}$ Times, Editorial (31 July 1899).

${ }^{56}$ W.T. Stead, 'What the Conference has Done', Parts I and II, Daily News (25-26 July 1899).

${ }^{57}$ W.T. Stead, 'Impressions at The Hague', in Perris, History of the Peace Conference, 2325.

${ }^{58}$ Ibid.

${ }^{59}$ G.H. Perris, 'Impressions at The Hague', in Ibid., 28. 
${ }^{60}$ Evans Darby, Peace Conference, 53.

${ }^{61}$ Ibid., 65 .

${ }^{62}$ International Peace Bureau brochure, 'Les Résultats de la Conférence de La Haye inaugurée le 18 mai 1899’, 19 March 1901, IPB 238/1.

${ }^{63}$ Bureau International de la Paix, Bulletin Officiel du IXe Congrès Universel de la Paix tenu à Paris du 30 septembre au 5 octobre 1900 (Berne, 1901), 21; d'Estournelles de Constant speech, 22 April 1901, cited in IPB brochure 'Les Résultats de la Conférence de La Haye', IPB 238/1.

${ }^{64}$ Cited in R.B. Mowat, The Life of Lord Pauncefote, first ambassador to the United States (London, 1929), 244.

${ }^{65}$ White diary entry, 5 August 1899, cited in White, Autobiography, II, 351; W.T. Stead, 'The Progress of the World', Review of Reviews (August 1899).

${ }^{66}$ d'Estournelles de Constant to Stead, 15 August 1899, STED 1/24.

${ }^{67}$ Pauncefote to Stead, 15 June 1901, STED 1/59.

${ }^{68}$ Perris to Ducommun, 23 October 1899, IPB 200/1.

${ }^{69}$ Green to Ducommun, 14 November 1899, IPB 200/2.

${ }^{70}$ Ceadel, Semi-Detached Idealists, 158.

${ }^{71}$ Cited in W. Sydney Robinson, Muckraker: The Scandalous Life and Times of W.T. Stead, Britain's First Investigative Journalist (London, 2012), 248.

${ }^{72}$ Ducommun to Stead, 4 December 1899, IPB 162/14.

${ }^{73}$ Eliza Riedi, 'The women pro-Boers: gender, peace and the critique of empire in the South African War', Historical Research, 86/231(2013), 111.

${ }^{74}$ E. Hobhouse, The Brunt of the War and Where It Fell (London, 1902). 
${ }^{75}$ Stead to Ducommun, 6 December 1900, IPB 201/9.

${ }^{76}$ IPB Circular, 'Aux sociétés de la paix au sujet de la guerre du Transvaal', 4 January 1900, IPB 200/8.

${ }^{77}$ D. Stevenson, Armaments and the Coming of War: Europe, 1904-1914 (Oxford, 1996).

${ }^{78}$ Warren F. Kuehl, Seeking World Order: The United States and International Organization to 1920 (Nashville, TN, 1969), 59.

${ }^{79}$ Hay circular to Representatives of the United States accredited to the Governments Signatories to the Acts of The Hague Conference, 1899, 21 October 1904, in 'Correspondence respecting the Convocation of a Second Peace Conference at the Hague', FO 412/79.

${ }^{80}$ Lansdowne to Choate [American ambassador, London], 7 November 1904, Ibid. See also Hay's communication to American representatives overseas (16 December 1904) in which he noted that the proposition had 'been received with general favour', the only dissenting voices emanating from Russia and Japan, although both governments had indicated that they would participate once existing hostilities had concluded. Enclosure in Choate to Lansdowne (17), 27 December 1904, Ibid.

${ }^{81}$ James Thompson, British Political Culture and the Idea of 'Public Opinion', 1867-1914 (Cambridge, 2013), 167.

${ }^{82}$ Ceadel, Semi-Detached Idealists, 166.

${ }^{83}$ de Martens, 'International Arbitration', 621-22.

${ }^{84}$ This is a point recognised by Best, 'Peace conferences', 633.

${ }^{85}$ Punch (24 May 1899). 
${ }^{86}$ de Martens, 'International Arbitration', 624; A Diplomatist at The Hague, 'The Peace Conference: Its Practical Results', North American Review, 168/511(1899), 773.

${ }^{87}$ Hamilton and Langhorne, Practice of Diplomacy, 158.

${ }^{88}$ Felix Adler, 'What Can We Do?', 16 April 1907, in Proceedings of the National Arbitration and Peace Congress, New York, April 14 th to 17 $7^{\text {th }}, 1907$ (New York, 1907), 211. ${ }^{89}$ Kaldor, Global Civil Society, 83. 